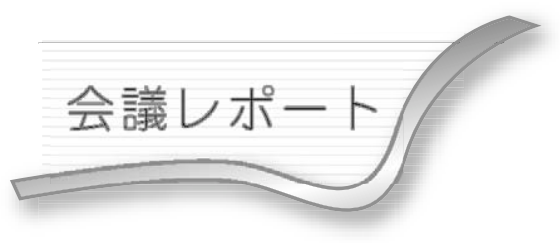

\section{5年映像情報メディア学会 冬季大会報告}

\author{
正会員 尾 鷲 仁 朗
}

\section{1.まえがき}

映像情報メディア学会では, 研究開発の発表・討論を通じて意 見を交換する場として, 毎年8月に年次大会, 12 月に冬季大会を開 催している.

今年の冬季大会は 12 月 1 日 (木), 2 日 (金)の両日, 工学院大学新 宿キャンパス (東京都新宿区) で開催された. 応募による一般講演 は年々増加傾向にあり, 今回も11部門で116件と前年を上回る講演 件数が集まった. 他に二つの特別企画で基調講演, 招待講演 10 件 が行われた.

一方，参加者数は，聴講参加者，講演者を合わせ 225 名であり， 講演件数が増えたにもかかわらず前年をやや下回った.

\section{2. 冬季大会の構成}

本年の冬季大会も, 例年に習った構成をとった. 両日共に, 午 前は, 五つの教室を用いて部門毎に同時進行で一般講演を行い, 午後は, 大教室を用いて単独で特別企画を行った.

応募による一般講演は，以下の11部門に分けて発表を行った。 「音声処理・セキュリティ (13件)」「情報ディスプレイ (14件)」「人 物・顔の認識とその応用 (11件) 」「無線・光伝送 (8件) 」「センシン グ\&コンシューマエレクトロニクス＆ストレージ (7件)」「インタ フェース, 画像・動画処理, その他 (12件) 」「画像・動画処理 $(13$ 件)」「CGと映像処理 (11件)」「ヒューマンインフォメーション (11 件)」「放送方式 (8件)」「放送現業の今を見る (8件)」.

初日の特別企画 I のテーマは「知識経済社会の到来に向けて〜 起業工学の進め〜」であり, 二日目の特別企画 II のテーマは「究極 の“メディア”は，何をつたえたいのか」であった.

初日の特別企画 I の後には, ハッピィーアワー(ビアパーティ) が開催されたここのハッピィーアワーでは, 参加者が自由な交流を 行うとともに, 研究奨励賞と学生優秀発表賞の授賞式が行われた.

研究奨励賞は今年で8回目になる．受賞対象は，2004年10月から 2005年9月までの間に, 本学会の 9 つの研究会で発表された798件の 技術報告である. この中から研究委員会ごとに選考を行い, 技術 委員会で確定した13名が受賞された。研究奨励賞受賞者には, 山 本英雄技術委員会委員長から賞状と賞牌が贈呈された.

学生優秀発表賞は, 年次大会と冬季大会で優秀な講演を行った 学生, 高専生を対象に贈呈する賞である. 今回の対象は, 8月に開 催された年次大会での講演65件である. 各部門の座長からいただ いた推薦を元に, 大会の実行委員会で検討・選定した7名の方が受 賞した. 学生優秀発表賞受賞者には, 冬季大会の実行委員長でも ある江藤副会長から賞状と記念品が贈呈された.

授賞式後は, 本格的な交流の場となり, 受賞者に研究内容を紹 介していただくなど, 若手研究開発者と先輩, 異分野の方々が直 接会話を交わす時間を持つことができた，会話の中から，それぞ れが刺激を受け, 楽しい中にも有意義な交流の場となった.

株式会社日立製作所，映像情報メディア学会調查担当理事
ハッピィーアワーは, 従来の有料郎親会に代えて参加費無料の 簡単なビアパーティ形式とした。これは，会員間の自由な交流の 場に，より広く，より多くの方々に参加いただくための試みであ ったが, 宣伝不足だったためか, 残念ながら例年と同程度の参加 者しか得られなかった. 引き続き, 会員にとって魅力的な企画を 立案し，実行していきたい。

\section{3. 講演の概要}

一般講演, 特別企画の概要は, 各部門の座長, 司会者他から事務 局へ提出された報告書, 事務局の作成した資料, 大会プログラム, 予稿集, 当日の配布資料などに基づき, 一部引用して報告する.

\section{1 一般講演の概要}

第1部門「音声処理・セキュリティ」

音声処理関連4件，伝送方式1件，セキュリテイ関連8件の講演が 行われた. 音声処理関連では, 音声合成, 自動採譜のための音高推 定法, 楽譜追従システムに関する報告が行われた．セキュリティ関 連では, プロバイダ認証方式, 個人認証, モザイク領域拡張法, ビ デオスクランブル技術, 電子透かしに関する報告が行われた.

13講演の内, 5 件は二つの組織の連名であった. 他の部門を含め, 複数組織の連名の投稿が多くあり, 産学官の連携が進んでいるこ とが感じられた。

\section{第2部門「情報ディスプレイ」}

講演件数が14件と, 最も講演件数が多い部門であった．講演内 容は, PDPの放電特性, 輪郭検出方法, プロジェクタの光学系, ホールドによるボヤケ, LCD, 有機ELディスプレイに関するもの であり，ディスプレイ全般にわたっており有意義であった.

\section{第3部門「人物・顔の認識とその応用」}

11件の講演中, 9件は同一の大学からの報告であり, 顔認識研究 の進むべき方向を探索している様子が伺えた．また，大規模デー タベースとの高速照合という課題をハードウェアから解決する試 みの報告もあり, 注目された.

\section{第4部門「無線・光伝送」}

8件の講演中，地上デジタル放送関連が6件あり，サービスエリ ア拡大に向けた研究報告が多く行われた。他に，ミリ波無線通信 技術，パワーアンプの故障検出装置に関する報告が行われた。大 学が関係する報告が全体の6割を占める中で，本部門と第11部門の み, 大学からの報告がなかったのが特徵である.

第5部門「センシング＆コンシューマエレクトロニクス＆ストレ ージ」

3分野合同で一つの部門としたため, 報告は, イメージセンサ, ネットワークカメラ, 画像修復アルゴリズム, X線サチコン, 防 振材, 光ディスクドライブ, ホログラム記録媒体に関するもので, 多岐に渡った内容となった。

第6部門「インタフェース，画像・動画処理，その他」

12 件の講演があり, テレビエージェントシステム, 手話映像の 再生速度, ロボットとのユーザインタフェース, CGを用いた動き 表示, 指紋抽出に扔ける画像補正, 点線の曲線化, 小画面への表 示方法, 人物追跡, 動画像手ぶれ補正, 顔姿勢推定, 像分離に関 する研究が報告された，応用を意識した発表が多く，実用的技術 開発が重要になっていることが感じられた。 また, 若手による発 表が多く, 聴講者数も最も多かった.

\section{第7部門「画像・動画処理」}

画像・動画処理として, 前日に行われた第6部門に続いており, 13件の講演が行われた. 圧縮符号化, 表情認識, 全方位画像から の透視投影画像変換, 割符生成, 輪郭の自動生成, クラックの自 動抽出, 鯛稚魚の識別, 障害物や車両検知に関する研究内容が報 告された。この部門も聴講者が多く, 研究開発者からの注目度が 高い分野である. 


\section{第8部門「CGと映像処理}

近年, 多視点映像に関する研究が多く, 発表の中心的存在とな っている. また, 今回は少なかったがホログラフィも今後増加の 傾向にある.

第9部門「ヒューマンインフォメーション」

人間の視聴覚の基本特性に関する研究が 2 件, 眼球運動の計測法 とその応用研究が 2 件, 新しい表示インタフェースが 1 件, 視覚補 助が 3 件, 画像認識処理の作業への応用研究が 3 件とさまざまな研 究報告が行われた。11件中10件は発表者が学生であり, 多くは研 究の初期段階での発表ではあったが，今後の発展が期待される.

第10部門「放送方式」

8件の講演があり, 方式変換, 放送通信連携サービス, 画質評価 法, 携帯端末を利用した視聴等に関する研究が報告された.

\section{第11部門「放送現業の今を見る」}

8件の講演が行われた．実際に運用中のものの報告もあったが， 全体としては研究開発中の発表が多く, 実現にはさらなる研究が 必要だと感じられた。番組制作のコストダウンをにらんだ報告が 目立った。

\section{2 特別企画の概要}

特別企画 I「知識経済社会の到来に向けて〜起業工学のすすめ〜」 起業工学に関する, 学理的な講演 2 件, 実践論3件の合計 5 件の講 演が行われた. 基調講演は東京理科大学の宮永教授により行われ, 2004年4月に開講された東京理科大学MOT (Management of Technology) 大学院について紹介された. MOTは「技術を利益に 変えること」と定義した後，3C分析 (Customer, Company, Competitor), MECE (Mutually Exclusive Collectively Exhaustive) 概念, SWOT分析などの紹介を受けた.

基調講演に続き，4件の招待講演が行われた. 九工大の川本教授 からSOC (System on Chip) に焦点を絞った日本の半導体事業の問 題点指摘, 松下の嶋田氏から苦難の末に強誘電体メモリーの事業 化に成功した要因紹介, E-INKの桑田氏からは電子ペーパベンチ ヤーの事業立上げと経営コンセプトの紹介, 立命館大の宮氏から は研究開発成果の事業化課程での課題の整理と「ステージゲート」 と呼ばれる要所要所での研究課題絞込み手法の紹介を受けた.

最後に, ドラッカーの明言,「知識によるイノベーションの失敗 は, 当事者が自分の専門領域以外のことに関心を持たず，自分の 技術に淫し，しばしば，顧客にとっての価值よりも技術的な複雑 さを価值としてしまうことにある.」を確認し閉会した。

(1) 開会挨拶

加納剛太 (高知工科大)

《基調講演》

(2) MOT (マネジメント オブテクノロジー) の勧め

宮永博史 (東京理科大)

\section{《招待講演》}

(3) Who makes Profits from SOC? - 日本半導体の方向 川本 洋 (九工大)

（4）強誘電体メモリーの開発と事業化プロセス 島田恭博 (松下電器)

(5) 電子ペーパの特長とマーケティング

(6) 研究開発と新規事業化

宮 正義 (立命館大/技術経営研)

(7) 閉会挨拶 倉重光宏 (松下電器)

特別企画 II「究極の“メディア”は，何をつたえたいのか」 最初に開会挨拶として, 本企画を立案, 推進いただいた北陸先
端大の宮原教授から, 問題提起と,「暗・静な環境に身を置いた場 で高度感性情報を提示して深い感動を喚起する」ことのできる技 術, その基礎研究を行う新分野の創生の必要性が話された.

続いて，5件の招待講演が行われた. 東京工科大学の相磯秀夫学 長からは, メディア学とは「人間・社会のコミュニケーションの すべてをメディアの視点から追及する学問」であって, 新しいメ ディアの課題として感性, 知識, 知能が挙げられた。

尚美学園大学の西教授からは,「今後, テレビ放送がインターネ ットに統合される」として，「ネット配信が本命となる」，「無線イ ンターネットと超小型情報端末が次世代情報端末の主力となる」, との考えが示された.

中央大の加藤教授は, 情報通信の技術課題とコミュニケーション の概念を整理し, コミュニケーションの課題を感性工学的にモデル 化し, 感性情報処理技術に求められる機能を分析・整理された.

尚美学園大学の大村教授は, バッハの楽曲の分析を通して後世 にまで残った楽曲とその理由, 作曲における基礎の重要性, メデ イアアートへの期待などをご自身の経験を交えながら熱く語られ た. また，VTRの再生によるメディアアートの実演も行われた.

最後に，講演いただいた登壇者を前に，深い感性のテクノロジ 一時限研究会幹事/KDDI研の川田氏の司会で活発なディスカッシ ヨンが行われた．全体として大幅に予定時間を超過してしまった が，登壇者による熱のこもった講演が強く印象に残った。
(1) 開会挨拶
宮原 誠 (北陸先端大)

\section{《招待講演》}

(2) メディア学が目指すもの 相磯英雄 (東京工科大)

(3) ホームエレクトロニクスとメディアPCの戦いの先に何があ るか? 西 和彦 (尚美学園大)

(4) 新メディア論 一深い感性のテクノロジー-

宮原 誠 (北陸先端大)

(5) 感性とメディアのロボティクス - 共生コミュニケーション への感性工学からのアプローチー 加藤俊一 (中央大)

(6) メディアアートへの期待

(7) ディスカッション

大村哲哉 (尚美学園大)

4.むすび

今回の冬季大会では, 新しい取組みと, いくつかの工夫を試み た．会員間の交流をより活発にすることを目的に，従来の有料の 懇親会に代えて, 無料のハッピィーアワー（ビアパーティ）を設け た. 残念ながら, 宣伝不足のためか参加者増には結びつかなかっ た。また，スムーズな運営を目指し，パソコンの立上げ準備をす る場所を設けた。大会として，まだまだ改善余地は多く，引き続 き会員に魅力を与える工夫をしていきたい.

最後に, 貴重な研究成果を発表・議論していただいた講演者, 聴講者, ご支援いただいた研究委員会, 企画・運営に当たってい ただいた部門幹事，実行委員会，当日の進行に当たっていただい た座長，司会，大会を支えていただいた事務局の方々にお礼申し 上げる.

(2006年1月16日受付)

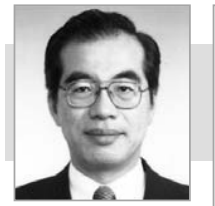

尾鷲 仁朗 1980 年, 東京工業大学理工学研究科 電気電子工学専攻修士課程修了. 同年, (株) 日立製 作所入社. ユビキタスプラットフォーム開発研究所に て, VTR, DVDカメラ, 組込みシステムの研究開発 に従事. その間, 研究開発管理, 事業企画業務にも従 事. 博士 (工学). 正会員. 